\title{
A CASE OF CRYPTOCOCCAL MENINGITIS
}

\author{
BY \\ D. C. CALDWELL AND S. S. RAPHAEL \\ From the Department of Pathology, Southend General Hospital
}

(RECEIVED FOR PUblication JUNe 15, 1954)

Cryptococcosis is a disease caused by the fungus Cryptococcus neoformans, one of the yeast-like organisms. The disease is world-wide in distribution, but most cases have been reported from the U.S.A. and Australia (Cox and Tolhurst, 1946). Some 200 cases are reported in the American literature (Carton, 1952 ; Evans and Harrell, 1952).

The interest of the case reported lies in its apparent rarity in this country, only 10 cases of cryptococcosis having been reported to date (Smith and Crawford, 1930 ; Greenfield, Martin, and Moore, 1938 ; Blair, 1943 ; Magarey and Denton, 1948 ; Daniel, Schiller, and Vollum, 1949 ; Galton and Whittick, 1950 ; Taylor, 1953 ; Symmers, 1953); in the demonstration of a possible differential stain for the cryptococcus in vivo; and in the use of a new fungicide in the treatment of the disease.

Cases occur more frequently in men than in women (Evans and Harrell, 1952), as do the other deep mycoses (Ainsworth, 1952). There does not appear to be an especial occupational hazard with this fungus, as with some others (Raphael and Schwarz, 1953 ; Conant, Smith, Baker, Callaway, and Martin, 1954).

The organism has a particular affinity for the central nervous system and causes either a localized granuloma or more often generalized meningitis (Daniel et al., 1949). Occasionally the fungus remains localized in the lung, which is believed by Conant et al. (1954) to be the portal of entry.

As regards the possible source of infection, Emmons (1951) isolated from the soil four strains virulent to mice and with typical fermentation reactions.

Carter and Young (1950) found pathogenic cryptococci in milk. Non-pathogenic cryptococci are found in the intestinal tract of man and on human skin (Benham and Hopkins, 1933). In this laboratory Dr. W. D. Nicoll (1954), examining stored blood from the hospital blood bank, found two bottles from over 300 examined contaminated with non-pathogenic cryptococci.

$C$. neoformans may be differentiated from the other yeast-like fungi without much difficulty. It differs from Candida in its possession, especially on first isolation from the body, of a large gelatinous capsule, and from Histoplasma capsulatum, Blastomyces dermatitidis and brasiliensis as well as Coccidioides immitis in its lack of biphasic forms of growth, since it remains in the "yeastphase" both at $37^{\circ} \mathrm{C}$. and at room temperature. $C$. neoformans grows readily on Sabouraud's glucose agar, on blood agar, and in nutrient broth in a few days. On solid media a creamy-white, shiny colony appears initially. Later it becomes honey coloured and shows a tendency to drip down the surface of the slope, again rather like honey. Fermentation reactions are not essential for identification, the other features being quite distinctive. Microscopically, single budding (in this case fungi presented occasional double budding) yeast cells are seen within a large capsule (Figs. 1 and 2). The yeast cell has a double outer wall and within the cell itself there is a small, ill-defined refractile area. The capsule has been shown to be polysaccharide in nature (Evans and Mehl, 1951) and is serologically active. Evans and Kessel (1951) were able to distinguish three antigenic types. The capsule becomes smaller on culture, but is still sufficiently apparent to permit differentiation from species of Candida.

The organism may be easily identified in cerebrospinal fluid by the addition of india ink or "nigrosin," when the capsule and its contained yeast cell clearly stand out against the black background (Fig. 3). Its presence may be suspected in the counting chamber either from the presence of budding cells, or from the oval shape of the cells and their relatively large size. They can be differentiated from red blood corpuscles, since the latter are refractile when slightly out of focus. If the specimen is spun down, the capsule may be thrown into sharp relief by other cells or debris collected around it (Fig. 4). Staining in the counting chamber by $0.1 \%$ toluidine blue gives the fungus a definite pink tinge leaving the capsule unstained, while white blood cells are stained deep blue and red blood cells remain unstained. 


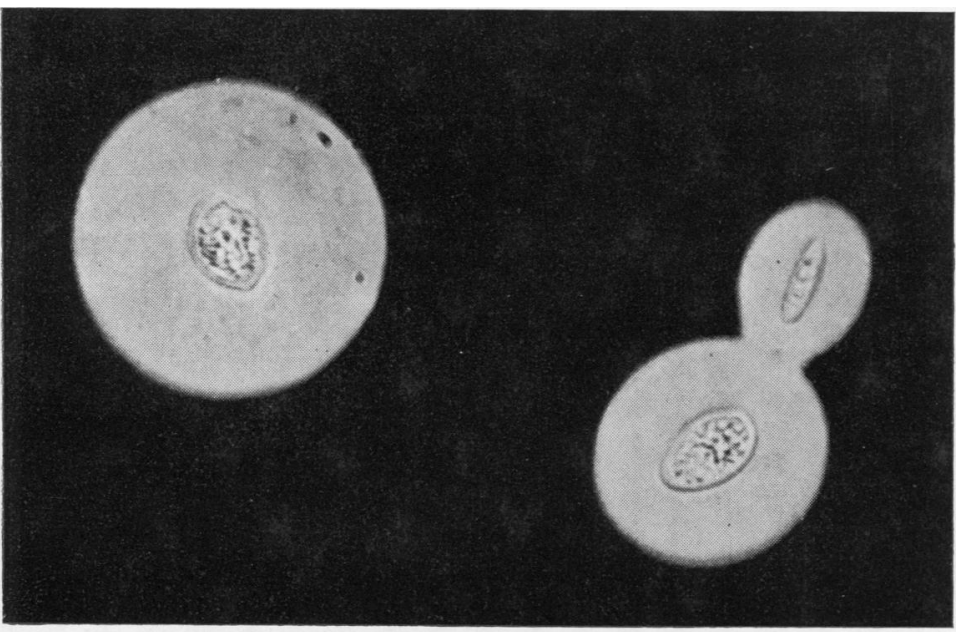

Fig. 1.-Budding and non-budding cryptococci from cerebrospinal fluid. India ink preparation, $\times$ 750.

\section{Case Report}

A 42-year-old carpenter and joiner was seen at the hospital on May 1, 1953. His chief complaint was pain in the neck and shoulders, of six weeks' duration. His past history was not helpful.

The illness began with an ill-defined infection of the upper respiratory tract followed by constant headache, pain in the back of the neck made worse by walking downhill, buzzing in the ears, and nausea. Later the pain radiated to the shoulders and anorexia appeared.

Physical examination on admission on May 5 disclosed Kernig's sign positive, neck movements restricted, and tenderness over the cervical spine but not over the shoulders. There was diplopia on lateral movement of the eyes in both directions. Some wasting of the left upper arm was noted. The biceps jerk was absent on both sides as was the knee jerk on the left. Plantar responses were flexor. On May 6 lumbar puncture showed cerebrospinal fluid pressure of $250 \mathrm{~mm}$. of water, Queckenstedt's test was normal,

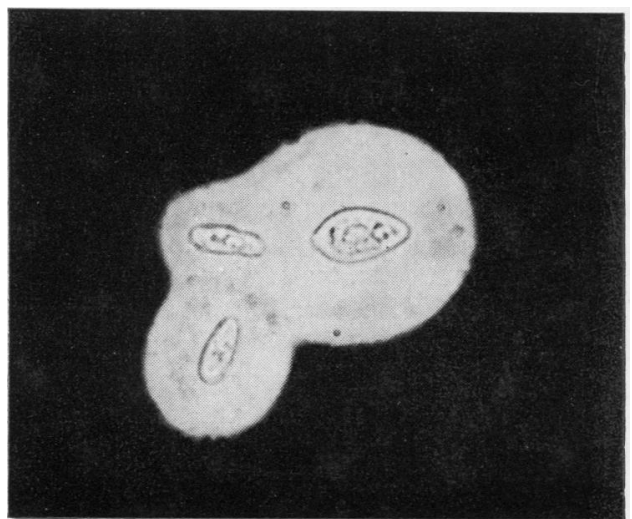

Fio. 2.-Double-budding cryptococcus from cerebrospinal fluid. India ink preparation, $\times 750$.
86 cells were found per c.mm. of fluid (15\% polymorphs and $85 \%$ lymphocytes), protein was $150 \mathrm{mg} . \%$, chloride (as $\mathrm{NaCl}$ ) $650 \mathrm{mg} . \%$, and globulin in excess. Lange's gold curve was 55432210 . The Wassermann test and Price's precipitation reaction were negative.

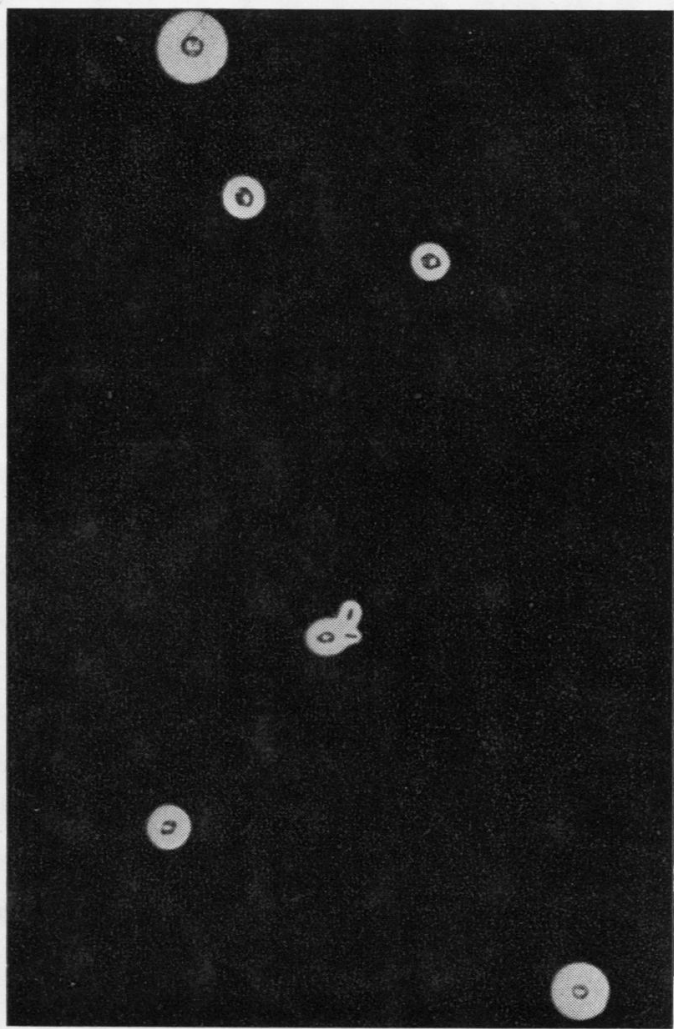

FIG. 3.-Cryptococci in cerebrospinai fluid. India ink preparation, $\times 180$. 
On May 13 findings were similar. On May 14 the sugar level was $14 \mathrm{mg} . \%$, and budding cryptococci were found in the cerebrospinal fluid.

On May 15 review of the neurological findings disclosed additional signs. The left pupil had become larger than the right; there was right facial weakness and weakness of flexion and extension of the right arm. Right-sided ptosis was noted on May 24. Meanwhile cultures of the C.S.F. at room temperature and at $37^{\circ} \mathrm{C}$. were positive in 48 hours.

Treatment with "actidione" was begun on May 29 ; $20 \mathrm{mg}$. was given intravenously for three days, then $40 \mathrm{mg}$. intravenously daily. and $10 \mathrm{mg}$. intrathecally on alternate days. On June 9 dosage was increased to $60 \mathrm{mg}$. intravenously and $20 \mathrm{mg}$. intrathecally daily. The total amount administered was $720 \mathrm{mg}$. intravenously and $200 \mathrm{mg}$. intrathecally. The patient's clinical condition progressively deteriorated, and he died on June 17 with bronchopneumonia. Necropsy was refused.

Cultures of cerebrospinal fluid were positive throughout the course of his illness, although the number of cryptococci per c.mm. varied (Table I).

Radiographs of the chest were reported as normal. The temperature during the period in hospital showed one peak to $100^{\circ} \mathrm{F}$. Two blood cultures taken at this time were sterile despite prolonged incubation. Cryptococci were not found in urine or in nasal or throat swabs. The E.S.R. on May 18 was normal.

\section{TABLE I}

COUNTS OF CRYPTOCOCCI AND WHITE BLOOD CELLS IN CEREBROSPINAL FLUID

\begin{tabular}{|c|c|c|c|c|}
\hline \multicolumn{3}{|c|}{ Date } & $\begin{array}{l}\text { Cryptococci } \\
\text { (per c.mm.) }\end{array}$ & $\begin{array}{l}\text { W.B.C. } \\
\text { (per c.mm.) }\end{array}$ \\
\hline 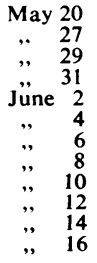 & $\begin{array}{l}\ldots \\
\ldots \\
\ldots \\
\ldots \\
\ldots \\
\ldots \\
\ldots \\
\ldots \\
\ldots \\
\ldots\end{array}$ & $\begin{array}{l}\ldots \\
\ldots \\
\ldots \\
\ldots \\
\ldots \\
\ldots \\
\ldots \\
\ldots \\
\ldots \\
\ldots \\
\ldots \\
\ldots\end{array}$ & $\begin{array}{r}63 \\
168 \\
240 \\
265 \\
122 \\
195 \\
88 \\
50 \\
31 \\
94 \\
98 \\
47\end{array}$ & $\begin{array}{r}7 \\
8 \\
12 \\
33 \\
22 \\
23 \\
96 \\
55 \\
43 \\
43 \\
44 \\
41\end{array}$ \\
\hline
\end{tabular}

\section{Bacteriological Investigations}

The probable source of infection was the soil. The patient was a carpenter and joiner who worked largely in the open air on building sites. He had been working in one particular area for the previous three years within a radius of one mile from his carpenter's shop. He worked mainly with Canadian fir and pine; occasionally he handled

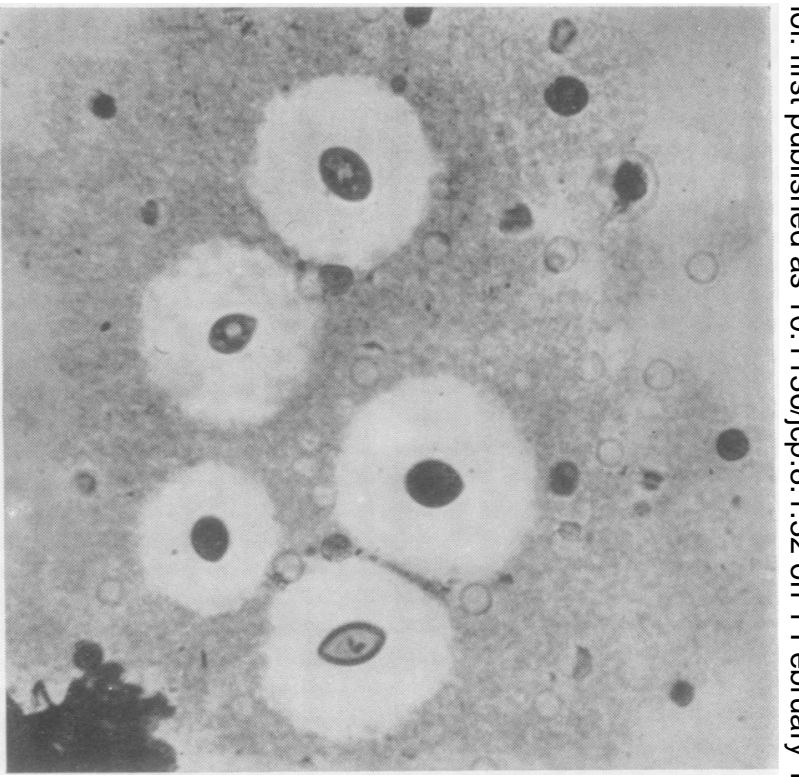

FIG. 4.-Cerebrospinal fluid depesit after centrifugation stained with $0.1^{\circ} \overrightarrow{\mathrm{C}}$ toluidine blue. Note the unstained capsule forming a halo around of the ovoid cryptococci against a background of debris and cells, the $r$ lack of capsule around iymphocytes, and the unstained red blood $\square$ cells, 500 .

felt and hardboard. Specimens of sweepings from his workshop, from the timber at the building site. of soil around several of the houses on the site, $\stackrel{\mathbb{Q}}{\mathbb{Q}}$ and of hardboard, felt, and sawdust from his bench $\underset{\vec{F}}{\Rightarrow}$ were obtained. The materials were ground up and $\frac{\text { 을 }}{3}$ emulsified in saline with penicillin (20 units $/ \mathrm{ml}$.) and streptomycin $(40 \mu \mathrm{g} . / \mathrm{ml}$.) added, and then injected intraperitoneally into white mice. The mice all died within a few weeks, but in none ato necropsy was there evidence of cryptococcal granulomatosis. Cultures were taken from peritoneum, brain, and lung in some animals, with similaro negative findings. No cause of death was determined.

The fungus and its capsule were measured using a micrometer ; the capsule diameter varied between $33 \mu$ and $60 \mu$ ( 20 cells measured), while the yeastĩ itself measured between $6 \mu$ and $21 \mu$ (average. diameter of capsule $44 \mu$, average diameter of 0 fungus $12 \mu$ ).

The organism was tested for its sensitivity too various therapeutic agents. By the disc sensitivityo method it appeared insensitive to penicillin, chloro $\frac{\text { D }}{2}$ mycetin, aureomycin, terramycin, para-amino? salicylic acid, streptomycin, and methylene blue.o Zones of growth-inhibition were found around? discs prepared with acriflavine, crystal violet, iso nicotinic acid hydrazide, sulphadiazine, and pent $\stackrel{\circ}{\circ}$ am dine. 
On the basis of these tests, tube sensitivity tests were set up with isonicotinic acid hydrazide, pentamidine, crystal violet, acriflavine and sulphadiazine.

A broth culture containing 670 viable organisms/c.mm. was used and the drugs under examination were added to give the required concentrations. Pentamidine was fungistatic in concentrations of $1.56 \mu \mathrm{g} . / \mathrm{ml}$., crystal violet at $150 \mu \mathrm{g} . / \mathrm{ml}$., and acriflavine at $60 \mu \mathrm{g} . / \mathrm{ml}$. Isonicotinic acid hydrazide and sulphadiazine did not inhibit growth.

Shortly afterwards actidione was obtained and tube-sensitivity tests with this agent were set up. Actidione was found to be fungicidal and fungistatic in a concentration of $0.625 \mu \mathrm{g} . / \mathrm{ml}$.; 0.3125 $\mu \mathrm{g} . / \mathrm{ml}$. was fungistatic but not fungicidal. Pentamidine under the same conditions was fungicidal at $25 \mu \mathrm{g}$. $/ \mathrm{ml}$., but at $1.56 \mu \mathrm{g}$. $/ \mathrm{ml}$., although fungistatic, it was not fungicidal.

A sample of cerebrospinal fluid which contained 31 cryptococci and 43 white blood cells per c.mm. on June 10 was Seitz filtered. The fluid was then examined again in the counting chamber; no organisms were now present. In each of two testtubes, $1 \mathrm{ml}$. of filtered cerebrospinal fluid was placed. To one of these tubes were added three drops of a broth culture of the strain of $C$. neoformans isolated in this case, and to the other three drops of broth culture of a strain of $C$. neoformans provided by Dr. R. W. Riddell. Subcultures of these specimens were positive after incubation, indicating that "actidione" had not reached a fungicidal level in the cerebrospinal fluid. Chemical methods of estimating "actidione" were not available.

\section{Animal Inoculation Experiments}

Six animals were injected intraperitoneally with cerebrospinal fluid on May 16, 1953. The results

TABLE II

FINDINGS IN MICE

\begin{tabular}{|c|c|c|c|c|}
\hline $\begin{array}{c}\text { Mouse } \\
\text { No. }\end{array}$ & Died & Killed & $\begin{array}{c}\text { Period of } \\
\text { Survival } \\
\text { (Days) }\end{array}$ & Findings \\
\hline $186 / 54$ & - & $27 / 54$ & 256 & $\begin{array}{l}\text { Subcutaneous toruloma } \\
\text { only }\end{array}$ \\
\hline $181 / 54 \mathrm{~A}$ & - & $27: 54$ & 256 & $\begin{array}{l}\text { Subcutaneous toruloma } \\
\text { only with calcification } \\
\text { of peripheral crypto- } \\
\text { cocci (Fig. 5) }\end{array}$ \\
\hline $\begin{array}{l}181 / 54 B \\
181 / 54 C\end{array}$ & - & $\begin{array}{l}27: 1 / 54 \\
27 / 1 / 54\end{array}$ & $\begin{array}{l}256 \\
256\end{array}$ & $\begin{array}{l}\text { No evidence of disease } \\
\text { Subcutaneous toruloma } \\
\text { only }\end{array}$ \\
\hline $2392 / 53$ & $17 / 11 / 53$ & 一 & 185 & $\begin{array}{l}\text { Subcutaneous toruloma } \\
\text { and lung cryptococcosis } \\
\text { (Fig. 6) }\end{array}$ \\
\hline $2442 / 53$ & $19 / 11 / 53$ & - & 187 & $\begin{array}{l}\text { Subcutaneous toruloma } \\
\text { and lung cryptococco- } \\
\text { sis }\end{array}$ \\
\hline
\end{tabular}

of these injections may best be seen in Table II. Brain, lung, liver, spleen, kidneys, and bowel were examined microscopically in every case, while especial features were examined as they occurred.

It is interesting to note that death only occurred spontaneously in those animals in which the infection spread to the lungs. Where the disease remained localized beneath the skin, the animal survived and appeared healthy despite relatively large cryptococcal tumours beneath the skin.

A second series of inoculations was made from saline-suspended cultures on May 28, and the results are listed in Table III.

\section{TABLE III}

INOCULATIONS OF SALINE-SUSPENDED SOLUTION IN MICE

\begin{tabular}{|c|c|c|c|c|}
\hline $\begin{array}{c}\text { Mouse } \\
\text { No. }\end{array}$ & Died & Killed & $\begin{array}{c}\text { Period of } \\
\text { Survival } \\
\text { (Days) }\end{array}$ & Findings \\
\hline $23 / 54$ & $5 / 1 / 54$ & - & 222 & $\begin{array}{l}\text { Cryptococci in lungs only } \\
\text { (only lungs examined) }\end{array}$ \\
\hline $24 / 54$ & - & $51 / 54$ & 222 & $\begin{array}{l}\text { Toruloma on abdominal } \\
\text { wall }\end{array}$ \\
\hline $183 / 54$ & $27 / 1 / 54$ & - & 244 & $\begin{array}{l}\text { Focal areas of chronic } \\
\text { inflammation in liver } \\
\text { and kidneys; no fungi } \\
\text { seen }\end{array}$ \\
\hline
\end{tabular}

Again it will be noted that localized cryptococcal infection within the anterior abdominal wall was compatible with survival. The lesions in mouse No. $183 / 54$ were interpreted as healed lesions.

The mice in both series survived six months or more, even when cryptococcosis was the cause of death. Other workers have been able to produce fatal lesions in less time. This fact, combined with the production of abdominal wall "torulomata," suggested that inoculations of both cerebrospinal fluid and suspensions of the organism had actually been made subcutaneously and not intraperitoneally. In order to test this theory a further three mice were later given intraperitoneal injections, and a control group intradermal injection, using at

TABLE IV

RESULTS OF INTRAPERITONEAL INJECTION IN THREE MICE

\begin{tabular}{c|c|c|c|c}
\hline $\begin{array}{c}\text { Mouse } \\
\text { No. }\end{array}$ & Died & Killed & $\begin{array}{c}\text { Period of } \\
\text { Survival } \\
\text { (Days) }\end{array}$ & Findings \\
\hline $182 / 54$ & $25 / 1 / 54$ & - & 10 & $\begin{array}{c}\text { Cryptococcal perispleni- } \\
\text { tis and interstitial pan- } \\
\text { creatitis } \\
\text { Cryptococci in brain, } \\
\text { kidney, and perisplenic } \\
\text { tissues } \\
\text { Cryptococci in brain, } \\
\text { lung, and abdominal } \\
\text { wall }\end{array}$ \\
\hline
\end{tabular}




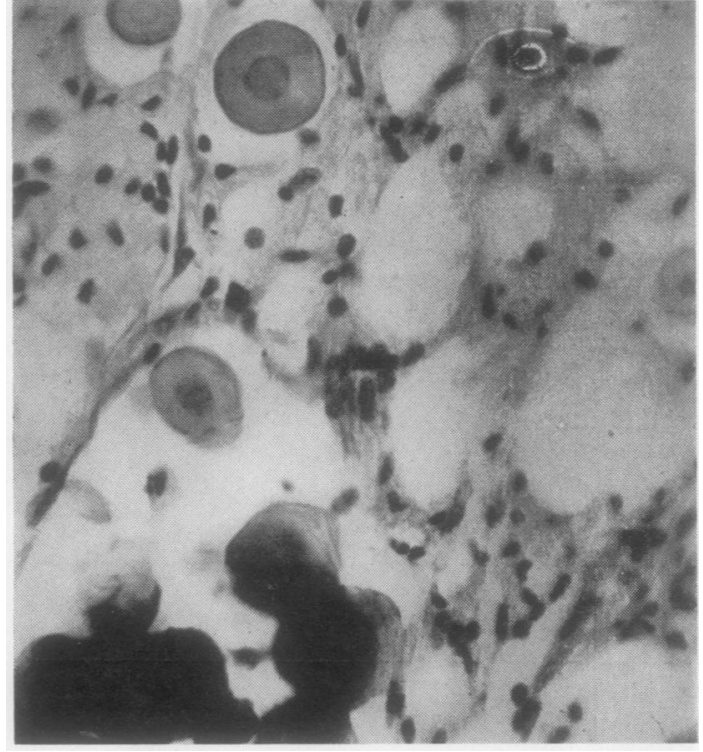

FIG. 5.-Calcification of cryptococci in abdominal " toruloma." Haematoxylin and eosin, $\times 500$.

the same time a heavier inoculum (40 million organisms to each mouse). The results appear in Table IV.

These results strongly suggested that the earlier inoculations had not indeed been made intraperitoneally. This is confirmed by the fact that the three control mice injected intradermally are still alive.

The histological appearances were similar to those previously described (Conant et al., 1954 ; Symmers, 1953), and the lack of cellular reaction to the cryptococcal bodies was striking (Fig. 6) except in the liver and kidney, where there was a mild inflammatory response. Specific staining methods showed that the fungi gave a positive reaction to the periodic-acid-Schiff method, to Meyer's mucicarmine, and to Gram's stain. Metachromasia was observed with methylene blue and crystal violet.

\section{Discussion}

Cryptococcal meningitis is not difficult to diagnose in the laboratory once the possibility has occurred to the examiner of the cerebrospinal fluid. It is quite possible for cryptococci to be mistakenly identified as lymphocytes or red blood corpuscles, but if the true nature of the bodies is suspected because of their lack of refractility, their ovoid shape, or their pink tinge on staining with $0.1 \%$ toluidine blue, then confirmation may be obtained by recognizing budding or, best of all, by an indiaink preparation. Culture presents no problem, and growth of the cryptococcus at $37^{\circ}$ is evidence of pathogenicity. Proof of pathogenicity is ob tained by intraperitoneal inoculation of white mies or rats. It should be remembered that six months may be necessary for the animals to die and $\overline{a x}$ necropsy the characteristic gelatinous granulomat should be sought and the fungus identifieg microscopically.

The other components of the cerebrospinal flui $\bar{\Phi}$ are abnormal, and the biochemical pattern mat resemble that found in other meningitides, pary ticularly tuberculous meningitis. Sugar is reduce (Wilson and Duryea, 1951) and may fall as low as $5 \mathrm{mg} . \%$; chlorides are lowered (Wilson and Duryea, 1951 ; Daniel et al., 1949 ; Magarey and Denton, 1948 ; Carton, 1952), while the proteiB content is raised and the globulin increased (Blair, 1943).

There is usually no dramatic pleocytosis, an this feature mirrors the morbid anatomical finding of remarkably little reaction to cryptococcal para sitism. Such cellular response as occurs is almost entirely lymphocytic. The Lange curve has beew reported as abnormal in cases where syphilis has been excluded by other serological tests (Blaip 1943 ; Wilson and Duryea, 1951: Magarey an

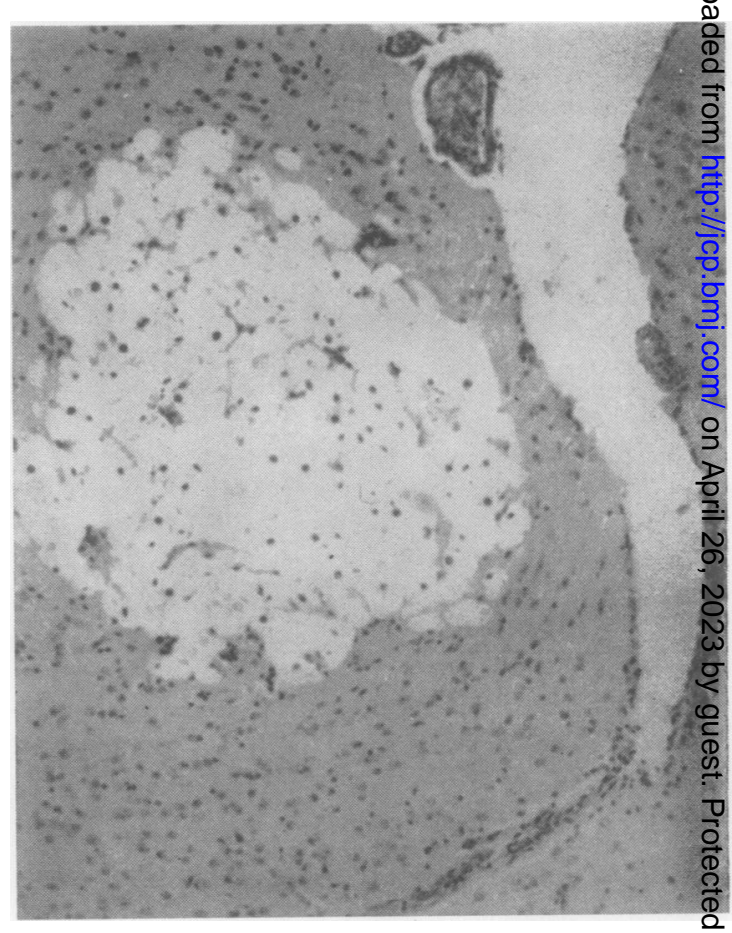

FIG. 6.-Mouse 185/54 brain lesion. Note lack of reaction to the cryptococcal colony. Haematoxylin and eosin, $\times 100$. 
Denton, 1948). Therapy may affect the protein and cells, but the sugar content is said by Carton (1952) to be the most sensitive index of the efficiency of treatment.

A comprehensive review has been made of the treatment of cryptococcosis of the central nervous system by Carton (1952). He reported improvement in two cases out of four, one being apparently cured. He suggests that " actidione" should be used, if possible in conjunction with fevertherapy, as was also suggested by Mosberg and Alvarez-DeChoudens (1951). In a personal communication to the authors Carton (1953) advised "polymyxin" as an adjuvant to therapy. Wilson and Duryea (1951) report one case cured with "actidione." Against the particular strain of $C$. neoformans isolated here " actidione" appeared to be the most active in vitro, but it did not appear to act in vivo.

There has been much speculation (Gendel, Ende, and Norman, 1950 ; Symmers, 1953) as to the possible relationship between cryptococcosis and Hedgkin's disease. Of 165 cases of cryptococcosis collected by Gendel, 14 had associated Hodgkin's disease. No evidence of lymphoma was found in this patient and lack of necropsy precluded further search. In view of the possibility of some relationship between the deep mycoses and the lymphomata, the former should be excluded as far as possible whenever the latter are diagnosed.

Most textbooks describe the cryptococcus as showing single budding, but several of the organisms found in this case possessed double buds; this was noted also by Emmons (1951). Multiple budding Blastomyces brasiliensis is excluded by the large capsule, by the absence of a mycelial phase on culture at room temperature, by the gross features of the colony, and by the histological appearances in inoculated mice.

\section{Summary}

A case of cryptococcal meningitis is presented. The mycological and cerebrospinal fluid findings, as well as the results of animal inoculation experiments, are discussed.
Methods of diagnosis, including the potentialities of $0.1 \%$ toluidine blue as a differential stain, are described.

Anti-fungal agents are examined.

We should like to thank Dr. T. Rowland Hill, under whose care the patient was admitted, for clinical details ; Dr. R. W. Riddell, of the Brompton Hospital and of St. John's Hospital for Diseases of the Skin, London, and Dr. Jan Schwarz, of the University of Cincinnatti, Ohio, U.S.A., for their confirmation of the identity of the organism; Mr. E. A. Yallop, F.I.M.L.T., Mr. R. M. M. Gould, and Mr. D. Baker for technical assistance ; and Mr. J. Wood, F.R.S.A., for assistance with the photography. Actidione was provided through the courtesy of the Upjohn Company, of Kalamazoo, Mich., U.S.A.

\section{REFERFNCES}

Ainsworth, G. C. (1952). Medical Mycolog.v. Pitman, London.

Benham, R. W., and Hopkins, A. M. (1933). Arch. Derm. Syph., Chicago, 28, 532.

Blair, D. (1943). J. ment. Sci., 89, 42.

Carter, H. S., and'Young, J. L. (1950). J. Path. Bact., 62, 271.

Carton, C. A. (1952). Ann. intern. Med., 37, 123.

- (1953). Personal communication to the authors.

Conant, N. F., Smith, D. T., Baker, R. D., Callaway, J. L., and Martin, D. S. (1954). Manual of Clinical Mycology, 2nd ed. Saunders, Philadelphia and London.

Cox, L. B., and Tolhurst, J. C. (1946). Human Torulosis. University Press, Melbourne.

Daniel, P. M., Schiller, F., and Vollum, R. L. (1949). Lancet, 1, 53.

Emmons, C. W. (1951). J. Bact., 62, 685.

Evans, E. E., and Harrell, E. R., Jnr. (1952). Univ. Mich. med. Bull., 18, 43.

and Kessel, J. F. (1951). J. Immunol., 67, 109. (Cited by Evans, 1952.)

- and Mehl, J. W. (1951). Science, 114, 10. (Cited by Evans, 1952.)

Galton, D. A. G., and Whittick, J. W. (1950). Demonstration at 82 nd Meeting of the Pathological Society of Gt. Britain and Ireland in London. (Cited by Symmers.)

Gendel, B. R., Ende, M., and Norman, S. L. (1950). Amer. J. Med.• $9,343$.

Greenfield, J. G., Martin, J. P., and Moore, M. T. (1938). Lancet, 2, 1154.

Magarey, F. R., and Denton, P. H. (1948). Brit. med. J., 1, 1082.

Mosberg, W. H., and Alvarez-DeChoudens, J. A. (1951). Lancet $1,1259$.

Nicoll, W. D. (1954). Unpublished observation.

Raphael, S. S., and Schwarz, J. (1953). Arch. industr. Hyg., 8, 154.

Smith, F. B., and Crawford,'J. S. (1930). J. Path. Bact., 33, 291.

Symmers, W. St. C. (1953). Lancet, 2, 1068.

Taylor, W. A. (1953). Demonstration at 86th meeting of Pathological Society of Gt. Britain and Ireland in London. (Cited by Symmers.)

Wilson, H. M., and Duryea, A. W. (1951). Arch. Neurol. Psychiat., Chicago, $66,470$. 